\title{
Are Older Workers Worthy of Their Pay? An Empirical Investigation of Age-Productivity and Age-Wage Nexuses
}

\author{
Ana Rute Cardoso \\ Institute for Economic Analysis (CSIC) \\ and IZA \\ Paulo Guimarães \\ University of South Carolina, \\ CEF.UP and IZA \\ José Varejão \\ Universidade do Porto, \\ CEF.UP and IZA
}

\section{Discussion Paper No. 5121 \\ August 2010}

\author{
IZA \\ P.O. Box 7240 \\ 53072 Bonn \\ Germany \\ Phone: $+49-228-3894-0$ \\ Fax: +49-228-3894-180 \\ E-mail: iza@iza.org
}

\begin{abstract}
Any opinions expressed here are those of the author(s) and not those of IZA. Research published in this series may include views on policy, but the institute itself takes no institutional policy positions.

The Institute for the Study of Labor (IZA) in Bonn is a local and virtual international research center and a place of communication between science, politics and business. IZA is an independent nonprofit organization supported by Deutsche Post Foundation. The center is associated with the University of Bonn and offers a stimulating research environment through its international network, workshops and conferences, data service, project support, research visits and doctoral program. IZA engages in (i) original and internationally competitive research in all fields of labor economics, (ii) development of policy concepts, and (iii) dissemination of research results and concepts to the interested public.
\end{abstract}

IZA Discussion Papers often represent preliminary work and are circulated to encourage discussion. Citation of such a paper should account for its provisional character. A revised version may be available directly from the author. 


\begin{abstract}

\section{Are Older Workers Worthy of Their Pay? An Empirical} Investigation of Age-Productivity and Age-Wage Nexuses*

Using longitudinal employer-employee data spanning over a 22-year period, we compare age-wage and age-productivity profiles and find that productivity increases until the age range of 50-54, whereas wages peak around the age 40-44. At younger ages, wages increase in line with productivity gains but as prime-age approaches, wage increases lag behind productivity gains. As a result, older workers are, in fact, worthy of their pay, in the sense that their contribution to firm-level productivity exceeds their contribution to the wage bill. On the methodological side, we note that failure to account for the endogenous nature of the regressors in the estimation of the wage and productivity equations biases the results towards a pattern consistent with underpayment followed by overpayment type of policies.
\end{abstract}

JEL Classification: J14, J24, J31

Keywords: $\quad$ aging, productivity, wages

Corresponding author:

Ana Rute Cardoso

IAE-CSIC

Campus UAB

08193 Bellaterra, Barcelona

Spain

E-mail: anarute.cardoso@iae.csic.es

\footnotetext{
*We are grateful to Charles Brown for his comments and to the Portuguese Ministry of Employment, Statistics Department, for access to the data used. The first author acknowledges the support of the Spanish Ministry of Science and Innovation (grant ECO2009-07958), the Barcelona GSE Research Network and the Government of Catalonia. CEF.UP is funded by Fundação para a Ciência e a Tecnologia.
} 


\section{Introduction}

The increasingly larger share of total population accounted for by older individuals - aging - is a key component of world population trends since the mid-twentieth century. This aging process is now pervasive and accelerating.

Concerns over its economic consequences have focused on the growing burden on social security systems around the world arising from the persistent decline of the potential support ratio. A less researched but potentially equally important consequence of this aging process concerns labor productivity, as the labor force is also becoming older and that may further impact on growth prospects, depending on how labor productivity varies with the age of the worker.

Individual productivity depends on the workers' abilities (physical and cognitive), as well as on their education and experience. While experience tends to increase with age, workers' abilities are expected to decline as individuals get older. Avolio and Waldman (1994) place around 30 the age at which cognitive and physical abilities start to decline sharply, whereas Skirbekk (2003) sets at around 50 the age at which productivity starts to decline. ${ }^{1}$ The decline in the productivity of labor with the age of the worker has been documented by a number of authors for specific occupations. ${ }^{2}$ However, as noted by Galenson and Weinberg (2000), the threshold at which productivity starts to decline may itself be subject to change over time, due to the changing nature of output demand and technology, as well as to the observed trend in the amount of job-training provided and the rate of training obsolescence (Bartel and Sicherman, 1993).

The fact that there is an important collective dimension to labor productivity (Aubert and Crépon, 2003) opens the way to analyzing the age-productivity nexus at the firm level rather than at the worker individual level. Results obtained with firm level data indicate that a larger share of old workers has a detrimental effect on firm productivity (Haltiwanger, Lane and Spletzer, 1999, Lallemand and Rycx, 2009), which is consistent with the findings obtained at the worker level.

The studies referred so far have concentrated only on the productivity side. None of them embraces a direct comparison of the productivity and wage profiles, to test whether the age-wage slope is steeper than the age-productivity slope. An early exception to this is offered by the work of Medoff and Abraham (1980),

\footnotetext{
${ }^{1}$ For a review of the literature on the evolution of cognitive skills over the life-cycle, see Skirbekk (2003).

${ }^{2}$ These include academia (McDowell, 1982, Diamond, 1986, and Oster and Hamermesh, 1988) or track and field road racing (Fair, 1994).
} 
who document a positive association, within hierarchical grade level, between pay and experience, not related or even negatively related to individual performance on the job (as rated by the supervisors). Their results are interpreted as evidence against the human capital on-the-job training model and are consistent with Lazear's model of deferred compensation (Lazear, 1979), which postulates that a pay scheme whereby workers are underpaid at the earliest stages of their careers within firms and overpaid later on is an admissible solution to the moral hazard problem the employer faces in a context of imperfect information on workers' actions.

The first study to focus entirely on wage and productivity age profiles was Hellerstein and Neumark's (1995). They have initiated a new track in the literature by proposing a simple but thoughtful method to test whether wage differentials traditionally captured by wage regressions are rooted in productivity differentials captured by production functions. The procedure relies on linked employer-employee data and consists essentially on estimating a production function and a wage function at the plant level, using a common specification, and then comparing the estimated coefficients across equations. Using firm level data from Israel, they estimate Cobb-Douglas production functions augmented with the inclusion of the shares of workers in the young, prime-age and older age brackets, finding that the upward sloping age-wage profile mirrors the upward sloping ageproductivity profile. Similar results were obtained by Hellerstein, Neumark and Troske (1999), while Hægeland and Klette (1999) found that the wage premium for workers with higher experience (more than 15 years) exceeds their relative productivity, whereas the opposite is true for workers with 8 to 15 years of experience.

Both the representativeness and the validity of these results are currently subject to intense debate. The need to ground the empirical work on longitudinal data so as to control more effectively for the relevant firm characteristics (including unobserved time-invariant characteristics) is now widely agreed upon (Hellerstein, Neumark and Troske, 1999). Firm-productivity shocks (which are, by definition, time-varying and therefore not captured by firm fixed-effects or similar methods) might as well bias the results, because firms may have more difficulty adjusting some types of labor than others due, for example, to the adoption of inverse seniority rules. In such cases, the bias in the estimation of older workers' productivity would arise out of the fact that changes in input shares are endogenous. Attempts to overcome this problem include using Arellano and Bond's (1991) estimator 
(Aubert and Crépon, 2003, Göbel and Zwick, 2009 and van Ours and Stoeldraijer, 2010) and two-stage regression methods (Dostie, 2006). ${ }^{3}$

In this article we also test the hypothesis that older workers are "overpaid", by comparing the contribution of different demographic groups to both the firm sales (which we take as a proxy for production) and its wage bill. Our work relies on administrative longitudinal data on workers and their firms of remarkable quality, which cover the entire workforce in the manufacturing and services private sector in Portugal. Problems commonly faced by panel datasets, such as panel attrition and over- or under-sampling of some groups of workers, are not present. Given its administrative nature and the fact that workers within each plant can have access to all the information reported, measurement problems are also reduced. Our analysis spans an unusually long period of more than twenty years.

Given the high quality of our database we believe that our results provide more reliable and precise estimates than previous studies. Indeed, all previous research on this topic is based on cross-sectional data or on panel data shorter than the length of the age intervals considered in the analysis. Hence, identification of the effects of age on wages and productivity depends on either cross-sectional variation or, for panel data studies, mostly on turnover of workers. In this latter case the scope to observe existing workers aging is reduced over a short period of time during which relatively few workers "cross the border" of the age brackets. Because we have data spanning 22 years and use 5-year age brackets, we are in a better position to capture aging of the firms' workforce and are thus able to obtain estimates of the parameters of interest based on within-firm variation largely due to the aging of each firm's workforce. The precision of our estimates is enhanced by the fact that we are able to introduce detailed information on worker characteristics, particularly the education level. We also note that our results are obtained from data that span over different stages of the business cycle and cannot be attributed to the timing of observation.

The paper is organized as follows. Section 2 describes the data. Section 3 presents the models under estimation. Section 4 discusses the results and section 5 concludes.

\footnotetext{
${ }^{3}$ Aubert and Crépon (2003) estimate first-differenced production and labor cost functions, treating the input levels and input shares as endogenous and using lagged values of those variables as instruments. Göbel and Zwick (2009) and Van Ours and Stoeldraijer (2010) also use an instrumental variable approach, estimating production and wage equations in first differences and using lagged values of the age structure as instrument for the change in the age structure. Dostie (2006) estimates productivity shocks in the first step and uses them as regressors to estimate the productivity equation in the second step.
} 


\section{Data source and descriptive statistics}

The data were gathered annually, between 1986 and 2008, ${ }^{4}$ by the Ministry of Employment in Portugal, in an inquiry that every plant with wage earners is legally obliged to fill in (Quadros de Pessoal). Information on all the personnel working for the plant in a reference week is reported. Public administration and domestic service are not covered; the coverage of agriculture is low, given its low share of wage earners. For the remaining sectors, the mandatory nature of the survey leads to an extremely high response rate and in practice the population of firms with wage earners in manufacturing and the services private sector is covered.

Each firm entering the database is assigned a unique identification code and it can thus be followed over time. Reported data include the firm's location, industry, employment, sales, ownership of equity capital (national, foreign, or public), and the worker's gender, age, schooling, occupation, seniority within the firm, monthly earnings (split into several components), and duration of work. Sales for year $t$ are reported in year $t+1$.

As in Haltiwanger et al. (1999) we measure productivity as total sales per labor unit. Although this is common in the literature, ${ }^{5}$ we recognize that total output (or valued added) would be a more accurate measure of productivity. The choice of sales for the computation of productivity was dictated by data availability. We also lack information on capital stock. This may be of less concern given that Foster et al. (2001) showed that labor productivity and total factor productivity are closely associated. In the same line, Dostie (2006) found that the age-productivity differentials were virtually identical if the model was estimated with and without controlling for the capital stock.

The fact that sales are reported the following year requires dropping the data on 2008 (the final year). Also, for firms that run out of business, the final observation must be discarded and if a firm fails to report in one particular year, data on the previous year will not be considered in our analysis (a constraint that led to dropping $13 \%$ of the firm observations in the initial dataset). Sales outliers ${ }^{6}$, a negligible share of the dataset $(0.1 \%)$, have also been dropped.

Wage-earners tracked in the panel dataset with a valid identification number, aged 18 to 65 years, are considered in the analysis. Extensive checks have been

\footnotetext{
${ }^{4}$ Worker level data is not available for 1990 and 2001.

${ }^{5}$ Other examples are Auberg and Crépon (2003), and Hellerstein et al., (1999).

${ }^{6}$ Sales above 10 times the percentile 99 or below half the percentile 1 .
} 
performed to guarantee the accuracy of the data, using the variables gender, date of birth and highest schooling level achieved. Wage outliers have been dropped. ${ }^{7}$

Firms in manufacturing and services have been kept for analysis, thus dropping firms in agriculture, fishing, mining and construction industries (10\% of the initial dataset). Only firms with more than 5 workers in the conditions specified above throughout the period under analysis have been kept. Given the small firm size structure in the Portuguese economy, this led to further dropping $42 \%$ of the observations firm-year in the original data set.

The final data set includes over 300,000 observations firm-year on 41,815 firms.

Table 1: Descriptive statistics

\begin{tabular}{|c|c|c|}
\hline Variable & Mean & Std. Dev. \\
\hline Av. sales per labor hour (log) & 3.495 & 1.212 \\
\hline Av. hourly wage (log) & 1.383 & 0.447 \\
\hline Employment (log) & 3.192 & 0.981 \\
\hline Age of the firm & 25.163 & 16.469 \\
\hline \multicolumn{3}{|l|}{ Industry (food, bev. omitted) } \\
\hline textiles, clothing, leather & 0.186 & \\
\hline wood, cork, furniture & 0.063 & \\
\hline paper, printing & 0.028 & \\
\hline chemicals, rubber, plastic & 0.030 & \\
\hline other non-metallic mineral prod. & 0.040 & \\
\hline metals, machinery & 0.102 & \\
\hline other manuf. & 0.007 & \\
\hline trade, repairs & 0.228 & \\
\hline hotels, restaurants & 0.070 & \\
\hline transport, communication & 0.037 & \\
\hline financial intermediation & 0.011 & \\
\hline real estate, serv. to co. & 0.054 & \\
\hline education & 0.023 & \\
\hline health, social serv. & 0.043 & \\
\hline sewage, refuse disposal & 0.003 & \\
\hline membership orgs. & 0.007 & \\
\hline recreational, cultural, sports activ. & 0.008 & \\
\hline other household, personal serv. & 0.005 & \\
\hline \multicolumn{3}{|l|}{ Ownership of capital (private omitted) } \\
\hline public & 0.007 & \\
\hline foreign & 0.051 & \\
\hline Lisbon & 0.329 & \\
\hline Share of workers aged 18-24 & 0.162 & 0.161 \\
\hline Share of workers aged $25-29$ & 0.171 & 0.121 \\
\hline Share of workers aged $30-34$ & 0.162 & 0.106 \\
\hline Share of workers aged 35-39 & 0.141 & 0.097 \\
\hline Share of workers aged $40-44$ & 0.120 & 0.093 \\
\hline Share of workers aged $45-49$ & 0.096 & 0.089 \\
\hline Share of workers aged $50-54$ & 0.073 & 0.081 \\
\hline Share of workers aged 55-59 & 0.048 & 0.066 \\
\hline Share of workers aged $60-65$ & 0.027 & 0.049 \\
\hline Share of workers w/ highest level university degree & 0.057 & 0.128 \\
\hline Share of workers w/ highest level high-school degree & 0.129 & 0.165 \\
\hline Share of workers w/ highest level 9 yrs education & 0.145 & 0.147 \\
\hline Share of workers w/ highest level 6 yrs education & 0.223 & 0.196 \\
\hline
\end{tabular}

\footnotetext{
${ }^{7}$ Wages above 10 times the percentile 99 or below half the percentile 1.
} 


\begin{tabular}{lcc}
\hline \hline \multicolumn{1}{c}{ Variable } & Mean & Std. Dev. \\
\hline Share of workers w/ highest level 4 yrs education & 0.421 & 0.279 \\
Share of female workers & 0.453 & 0.323 \\
Year & & \\
1987 & 0.040 & \\
1988 & 0.042 & \\
1989 & 0.041 & \\
1991 & 0.044 \\
1992 & 0.044 \\
1993 & 0.043 \\
1994 & 0.045 \\
1995 & 0.044 \\
1996 & 0.044 \\
1997 & 0.047 & \\
1998 & 0.048 & \\
1999 & 0.050 & \\
2000 & 0.051 & \\
2002 & 0.056 & \\
2004 & 0.058 & \\
2005 & 0.061 & \\
2006 & 0.064 \\
2007 & 0.067 & \\
& & 0.069 \\
\hline
\end{tabular}

\section{Empirical model}

Our empirical approach is based on the estimation of one firm-level wage equation and one firm-level productivity equation that share a common specification. The aim is to compare across equations the estimates obtained for the coefficients of the same regressors, our primary interest being the coefficients of the age-related covariates.

The estimated firm-level average wage equation is:

$$
\ln \left(\omega_{i t}\right)=\alpha^{\omega}+\beta^{\omega} \ln \left(L_{i t}\right)+\sum_{j} \gamma_{j}^{\omega} l_{j, i t}+\delta^{\omega} X_{i t}+\varepsilon_{i t}^{\omega},
$$

where subscript $i$ denotes the firm, subscript $t$ stands for time and subscript $j$ denotes labor types. $\omega_{i t}$ denotes the firm-level average hourly wage, ${ }^{8} L_{i t}$ is total labor (as measured by the total number of employees at the firm), $l_{j, i t}$ is the share of labor input $j\left(e . g\right.$., workers with age $j$ ) and $X_{i t}$ is a vector of firm specific characteristics.

The firm-level productivity equation is:

$$
\ln \left(q_{i t}\right)=\alpha^{q}+\beta^{q} \ln \left(L_{i t}\right)+\sum_{j} \gamma_{j}^{q} l_{j, i t}+\delta^{q} X_{i t}+\varepsilon_{i t}^{q},
$$

\footnotetext{
${ }^{8}$ The monthly wage bill was computed for firm $j$ at time $t$ as $W_{j t}=\sum_{i}(b w+r e g)_{i j t}$, where $i$ refers to the worker, $b w$ stands for base-wage, and reg are other regularly paid components of the worker's pay, all evaluated in gross terms. Similarly, total hours refers to the sum of monthly hours reported for all workers in the firm.
} 
where $q_{i t}$ is a measure of productivity (i.e., sales per yearly worker-hour ${ }^{9}$ ), and all other variables carry the exact same meaning as in the wage equation. All monetary variables were deflated using the GDP deflator, base 2008.

As noted by Hægeland and Klette (1999) and Haltiwanger et al. (1999), these two equations can be interpreted as simple descriptive equations with no behavioral content. Both simply relate average wage and productivity levels to firm characteristics and the composition of its workforce. However, as also noted by Hægeland and Klette (1999), the wage equation is the firm-level equivalent of the standard wage equation commonly estimated with worker data. Worker characteristics usually controlled for in worker-level regressions show up as the share of the corresponding type of labor at the firm level and firm-specific characteristics, such as size and age, show up untransformed.

Similarly, van Ours and Stoeldraijer (2010) show that the productivity equation can be derived from a standard Cobb-Douglas production function augmented to include controls for firm-specific characteristics. Structural interpretation of the productivity equation is possible under the assumption that workers of different age groups are substitutes for each other, although their marginal productivity is allowed to differ (for details, see van Ours and Stoeldraijer, 2010). Under these assumptions, $\alpha^{q}$ may be interpreted as the marginal productivity of labor of the age-reference worker type, $\beta^{q}$ as the total labor elasticity of output, and $\gamma_{j}^{p}$ the contribution of labor type $j$ relatively to the baseline category for the firm's productivity. From the wage equation, parameters $\gamma_{j}^{w}$ also measure the differential contribution of labor type $j$ to the firm's average hourly wage.

The two equations share the same set of regressors. Vector $l_{j, i t}$ includes the share of the total number of worker-hours that is accounted for by each type of labor considered. We defined labor types according to gender (females), highest level of education achieved (university degree, high school degree, 9, 6 or 4 years of education), and age (nine categories, defined on a 5-year basis, from 18 to 65 years of age, with the category 35-39 omitted). Vector $X_{i t}$ includes controls for the firm age (years since the firm was created), firm size (log of the total number of workers), origin of capital (foreign or public, with private as the omitted category), industry (20 dummy variables), location (one dummy variable equal to 1 if the firm is located in the Lisbon area), and time (19 year dummies).

We start by estimating equations (1) and (2) by pooled OLS. Yet, for OLS

\footnotetext{
${ }^{9}$ The yearly worker-hours were computed as 12 times the reported monthly hours.
} 
estimators to remain unbiased it is essential that all the regressors in the two equations are uncorrelated with the corresponding error term. This is unlikely the case in the event that firm-level productivity/wages and the age-structure of its workforce are jointly determined by an unobserved third factor. ${ }^{10}$

To address this difficulty, we also estimate equations (1) and (2) using a specification with firm fixed-effects (FE). In doing so, we are assuming that the error terms $\left(\varepsilon_{i t}\right)$ in the two equations may be decomposed into a time-invariant unobserved effect $\left(a_{i}\right)$ and an idiosyncratic error term $\left(u_{i t}\right)$ :

$$
\varepsilon_{i t}=a_{i}+u_{i t}
$$

Although fixed-effects estimation appropriately solves the heterogeneity bias (assuming that the omitted regressors are constant over time), it does not handle the endogeneity bias that will be present if the dependent variables in the two equations and the age-structure of its workforce are jointly determined such that shocks affecting productivity and wages also translate into changes in the composition of the workforce. Positive and negative productivity shocks are expected to lead to the hiring and firing of workers, with younger workers being over-represented in both flows. Furthermore, an omitted variables bias will also persist after fixedeffect estimation if some of the omitted variables are not constant over time.

To account for both sources of endogeneity we also estimate equations (1) and (2) in first-differences by the generalized method of moments (GMM). All age shares are instrumented with the corresponding levels lagged two and three periods (years). The implicit assumption is that productivity shocks in one period, although possibly correlated with the contemporaneous variations in labor shares, are uncorrelated with their levels two and three years before.

Hence, our final step is to estimate by GMM the two equations:

$$
\Delta \ln \left(\omega_{i t}\right)=\beta^{\omega} \Delta \ln \left(L_{i t}\right)+\sum \gamma_{j}^{\omega} \Delta l_{j, i t}+\delta^{\omega} \Delta X_{i t}+\Delta \varepsilon_{i t}^{\omega}
$$

and

$$
\Delta \ln \left(q_{i t}\right)=\beta^{q} \Delta \ln \left(L_{i t}\right)+\sum \gamma_{j}^{q} \Delta l_{j, i t}+\delta^{q} \Delta X_{i t}+\Delta \varepsilon_{i t}^{q}
$$

using $l_{j, i(t-s)}$ with $s=2,3$ as instruments for $\Delta l_{j, i t}$, with $j$ being equal to all the age-shares considered. ${ }^{11}$

\footnotetext{
${ }^{10}$ This is specially a concern in our case because, due to data limitations, we do not control for the capital stock, even though the problem may be mitigated as we include among the regressors the age and size of the firm and the industry it belongs to.

${ }^{11}$ Given the fact that we do not have other instruments available but lagged values of the endogenous variables
} 


\section{Wage and productivity age profiles}

Figure 1 and the first column in tables 2 and 3 report the results of our basic specification, the OLS model. Although obtained from firm-level data, the inverted $\mathrm{u}$-shaped wage-earnings profile is rather similar to the one usually detected in worker-level wage regressions. Up to the interval between 50 and 54 years of age, an increase of one percentage point in the share of workers in each age bracket has an increasingly large impact on the firm's average hourly wage. Only for the top two age brackets (above the age of 55) does that effect decline. The ageproductivity profile also has an inverted u-shaped pattern and reaches its peak at the 40-44 age range. After that, there is a marked decline, with older workers experiencing an increasingly smaller contribution to the firm's productivity.

Both results are consistent with an human capital interpretation, as they indicate that, up to a certain age, older (more experienced) workers become more productive and get paid higher wages.

However, if we compare the two profiles, we see that the changes in wages associated with increasing age are consistently larger than the changes in productivity.

Such a pattern lends support to the existence of a mechanism of deferred compensation over the life-cycle, with worker wages always growing faster than productivity. For example, with everything else constant, replacing workers aged 35-39 (the reference category) by workers aged 50-54 would lead to a decline in average productivity of $0.061 \%$ per percentage point change, but an increase in average wages of $0.175 \% .^{12}$

Estimation of the productivity and wage equations by firm fixed-effects conveys a fundamentally similar result - see Figure 2 and column 2 in tables 2 and 3-, even if the wage profile is slightly different in the OLS and FE regressions. Once we control for firm unobserved time-invariant characteristics, we find that larger shares of older workers are monotonically associated with higher average wages. The productivity profile indicates declining productivity starting now at age 30 . Compared to the OLS estimates, these results indicate that the share of oldest workers is indeed larger in low-pay workplaces.

Our preferred specification accounts for the possible endogeneity of changes in the composition of the workforce, via GMM estimation, and the detected patterns

(in levels), we chose to use the minimum number of lags that pass the Hansen test, so as to maximize the number of observations used in the estimation.

${ }^{12}$ One percentage point equals 0.01 in the scale of measurement of the shares. 
change slightly (see figure 3 and column 3 in tables 2 and 3). As expected, the estimated standard errors are now larger, specially in the case of the productivity equation. Now, the age-productivity curve is upward sloping throughout most age ranges and peaks at the 50-54 age bracket. The age-wage profile shows an inverted$\mathrm{u}$ shaped as in the OLS case. ${ }^{13}$ However, given the large confidence intervals, we cannot discard the possibility of a basically flat age-wage profile starting at age 35.

A steep age-productivity profile indicates considerable on-the-job training in the early years of participation in employment, a fact also noted by Hægeland and Klette (1999). However, the fact that the age-wage profile becomes less steep than the age-productivity profile around age 30-34, and essentially flat in the primeage range, also indicates that the returns to training are appropriated by workers earlier on and by employers only subsequently.

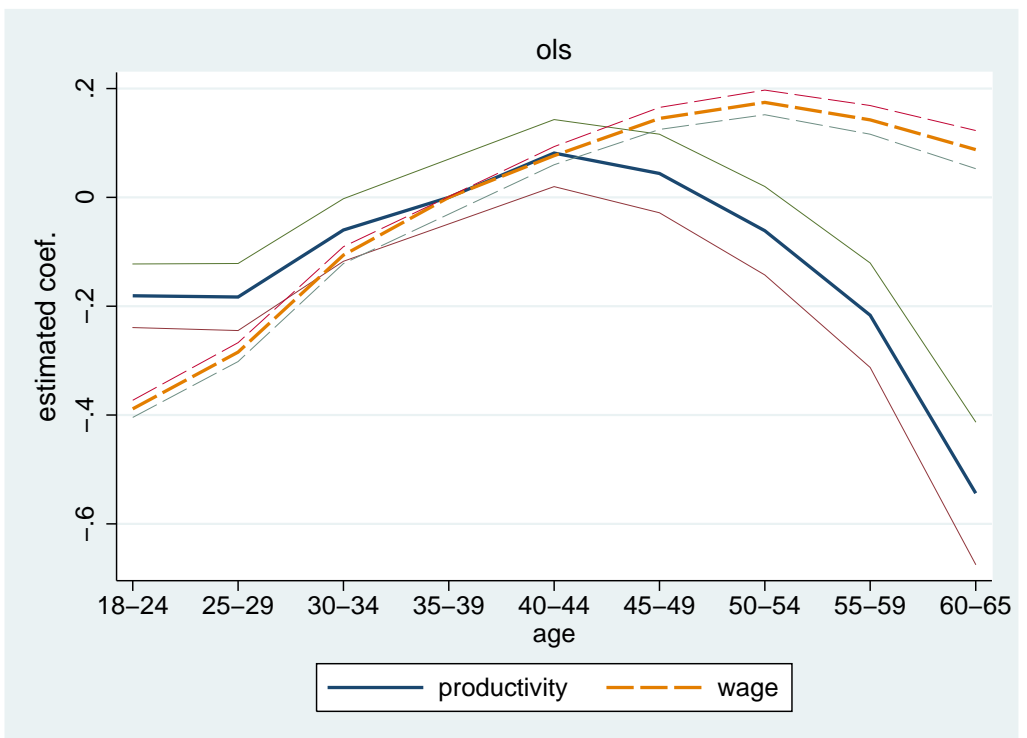

Figure 1: Production and wage cost functions, Ordinary Least Squares estimation, ECONOMY. Source: Computations based on Portugal (1986 to 2008).

We note that our productivity profiles are broadly consistent with previous findings. Our final estimates indicate that workers reach their maximum contribution to productivity at the age 50-54, a result that confirms Skirbekk's (2003) estimate of around 50. This result is also similar to that obtained by Göbel and Zwick (2009).

As in previous studies based on cross-section data and broad age intervals (Hellerstein and Neumark, 1995, Hellerstein et al.,1999) or short panels (Aubert and Crépon, 2003, Dostie, 2006, van Ours and Stoeldraijer, 2010), our results on

\footnotetext{
${ }^{13}$ Note that the more compressed scale in Figure 3 shows an apparently flatter wage profile.
} 


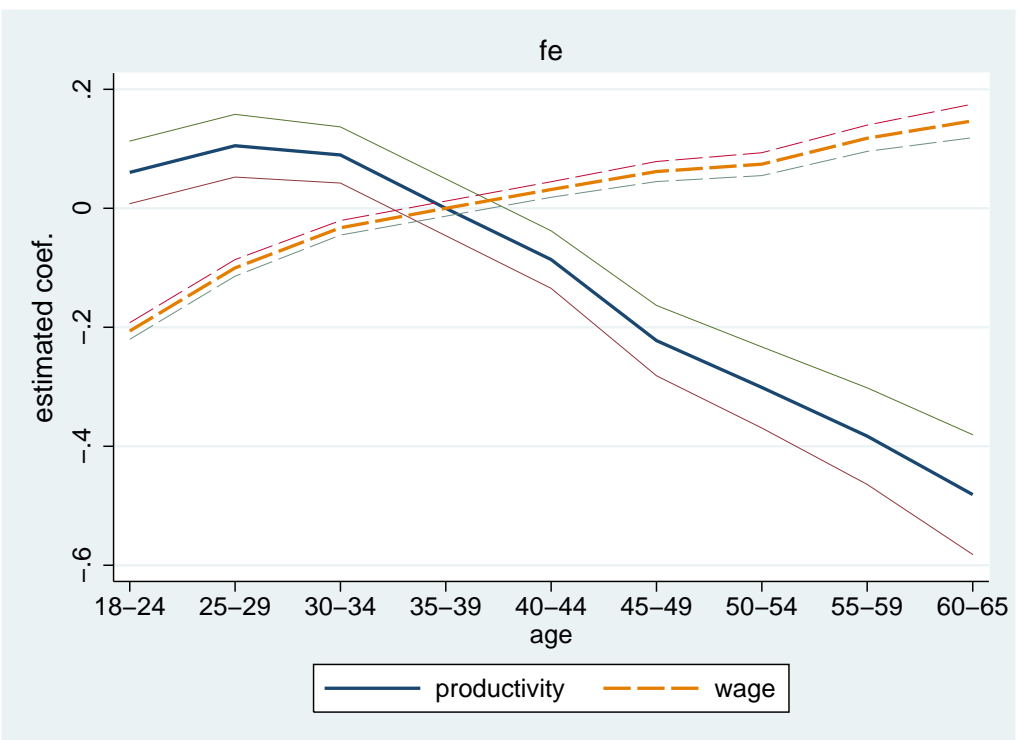

Figure 2: Production and wage cost functions, Fixed Effects estimation, economy. Source: Computations based on Portugal (1986 to 2008).

wages also indicate that workers are paid according to their relative contribution to output, though not over their entire working-life. Productivity increases are passed on to young workers under the form of higher wages, but not to prime-age or old workers.

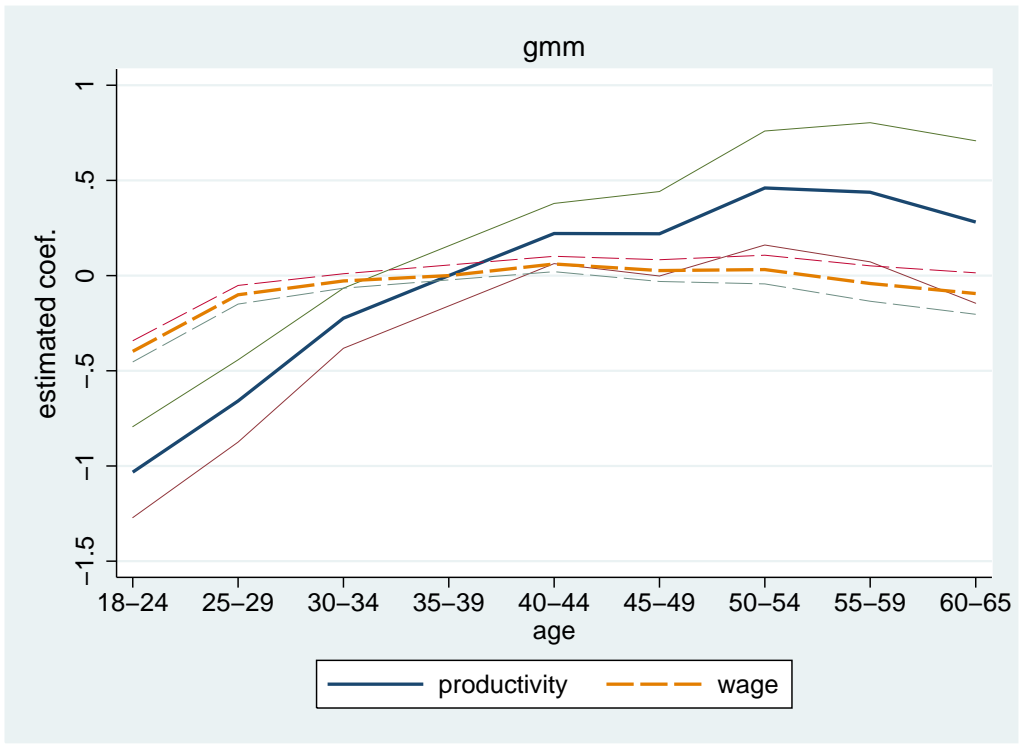

Figure 3: Production and wage cost functions, General Method of Moments, econOMY. Source: Computations based on Portugal (1986 to 2008).

Finally, as a robustness check we re-estimate all our models separately for manufacturing and for services. Results in Figures 4 to 9 in appendix indicate that the age-wage and age-productivity profiles are very similar in the two sub-samples.

The use of a more adequate estimation method (GMM) highlights that the 


\begin{tabular}{|c|c|c|c|}
\hline & $\frac{\text { OLS }}{(1)}$ & $\frac{\mathrm{FE}}{(2)}$ & $\frac{\text { GMM }}{(3)}$ \\
\hline$\overline{\text { Employment (log) }}$ & $\begin{array}{c}.050 \\
(.001)^{* * *}\end{array}$ & $\begin{array}{c}.015 \\
(.002)^{* * *}\end{array}$ & $\begin{array}{c}.004 \\
(.003)\end{array}$ \\
\hline Age of the firm & $\begin{array}{c}.0009 \\
(.00008)^{* * *}\end{array}$ & & \\
\hline Public ownership & $\begin{array}{c}.079 \\
(.012)^{* * *}\end{array}$ & & \\
\hline Foreign ownership & $\begin{array}{l}.165 \\
(.006)^{* * *}\end{array}$ & & \\
\hline Lisbon & $\begin{array}{c}.064 \\
(.003)^{* * * *}\end{array}$ & & \\
\hline Share of workers aged $18-24$ & $\begin{array}{l}-.389 \\
(.008)^{* * *}\end{array}$ & $\begin{array}{l}-.206 \\
(.007)^{* * *}\end{array}$ & $\begin{array}{c}-.398 \\
(.028)^{* * *}\end{array}$ \\
\hline Share of workers aged 25-29 & $\begin{array}{l}-.284 \\
(.009)^{* * *}\end{array}$ & $\begin{array}{l}-.100 \\
(.007)^{* * *}\end{array}$ & $\begin{array}{l}-.101 \\
(.025)^{* * *}\end{array}$ \\
\hline Share of workers aged $30-34$ & $\begin{array}{l}-.106 \\
(.008)^{* * *}\end{array}$ & $\begin{array}{l}-.033 \\
(.006)^{* * *}\end{array}$ & $\begin{array}{l}-.028 \\
(.019)\end{array}$ \\
\hline Share of workers aged $40-44$ & $\begin{array}{c}.077 \\
(.008)^{* * * *}\end{array}$ & $\begin{array}{c}.032 \\
(.007)^{* * * *}\end{array}$ & $\begin{array}{c}.061 \\
(.021)^{* * *}\end{array}$ \\
\hline Share of workers aged $45-49$ & $\begin{array}{c}.145 \\
(.010)^{* * * *}\end{array}$ & $\begin{array}{c}.062 \\
(.009)^{* * * *}\end{array}$ & $\begin{array}{l}.026 \\
(.029)\end{array}$ \\
\hline Share of workers aged $50-54$ & $\begin{array}{c}.175 \\
(.012)^{* * * *}\end{array}$ & $\begin{array}{c}.074 \\
(.010)^{* * * *}\end{array}$ & $\begin{array}{l}.032 \\
(.038)\end{array}$ \\
\hline Share of workers aged $55-59$ & $\begin{array}{c}.142 \\
(.013)^{* * * *}\end{array}$ & $\begin{array}{c}.118 \\
(.011)^{* * * *}\end{array}$ & $\begin{array}{l}-.042 \\
(.047)\end{array}$ \\
\hline Share of workers aged $60-65$ & $\begin{array}{c}.088 \\
(.018)^{* * * *}\end{array}$ & $\begin{array}{c}.147 \\
(.014)^{* * *}\end{array}$ & $\begin{array}{l}-.094 \\
(.056)^{*}\end{array}$ \\
\hline Share of workers w/ highest level university degree & $\begin{array}{c}1.943 \\
(.019)^{* * *}\end{array}$ & $\begin{array}{c}1.049 \\
(.025)^{* * *}\end{array}$ & $\begin{array}{c}.875 \\
(.056)^{* * *}\end{array}$ \\
\hline Share of workers w/ highest level high-school degree & $\begin{array}{c}.996 \\
(.017)^{* * *}\end{array}$ & $\begin{array}{c}.465 \\
(.020)^{* * * *}\end{array}$ & $\begin{array}{c}.371 \\
(.052)^{* * *}\end{array}$ \\
\hline Share of workers w/ highest level 9 yrs school & $\begin{array}{c}.711 \\
(.016)^{* * *}\end{array}$ & $\begin{array}{c}.332 \\
(.019)^{* * *}\end{array}$ & $\begin{array}{c}.283 \\
(.050)^{* * *}\end{array}$ \\
\hline Share of workers w/ highest level 6 yrs school & $\begin{array}{c}.454 \\
(.015)^{* * *}\end{array}$ & $\begin{array}{c}.205 \\
(.017)^{* * *}\end{array}$ & $\begin{array}{c}.191 \\
(.048)^{* * *}\end{array}$ \\
\hline Share of workers w/ highest level 4 yrs school & $\begin{array}{c}.230 \\
(.014)^{* * *}\end{array}$ & $\begin{array}{l}.125 \\
(.016)^{* * *}\end{array}$ & $\begin{array}{l}.081 \\
(.044)^{*}\end{array}$ \\
\hline Share of female workers & $\begin{array}{c}-.243 \\
(.004)^{* * *}\end{array}$ & $\begin{array}{l}-.203 \\
(.008)^{* * *}\end{array}$ & $\begin{array}{c}-.198 \\
(.011)^{* * *}\end{array}$ \\
\hline Const & $\begin{array}{l}.604 \\
(.152)^{* * *}\end{array}$ & $\begin{array}{l}0.901 \\
(.177)^{* * *}\end{array}$ & $\begin{array}{c}.009 \\
(.001)^{* * *}\end{array}$ \\
\hline Obs. & 301,328 & 301,328 & 112,861 \\
\hline$R^{2}$ & .744 & .918 & .04 \\
\hline$F$ statistic & $2,906.4$ & $1,838.1$ & 19.44 \\
\hline Hansen-J statistic & & & $\begin{array}{l}8.936 \\
{[0.348]}\end{array}$ \\
\hline
\end{tabular}

Table 2: Wage REgressions (ordinary LEASt SQUARES, FIXED EFFECTS, AND GENerAL METHOD OF MOMENTS).

Note: The OLS regression includes controls for the industry (20 dummy variables) and time (19 dummy variables); the $\mathrm{FE}$ regression includes controls for time (19 dummy variables). In the GMM regression, the equation is estimated in first differences, with the shares of worker ages lagged 2 and 3 periods used as instruments. Firm-clustered robust standard-errors in parenthesis. P-value in brackets. Source: Computations based on Portugal, MTSS (1986-2008). 


\begin{tabular}{|c|c|c|c|}
\hline & $\frac{\text { OLS }}{(1)}$ & $\frac{\mathrm{FE}}{(2)}$ & $\frac{\text { GMM }}{(3)}$ \\
\hline Employment (log) & $\begin{array}{l}.001 \\
(.005)\end{array}$ & $\begin{array}{c}.292 \\
(.008)^{* * *}\end{array}$ & $\begin{array}{c}-.641 \\
(.014)^{* * *}\end{array}$ \\
\hline Age of the firm & $\begin{array}{c}.004 \\
(.0003)^{* * *}\end{array}$ & & \\
\hline Public ownership & $\begin{array}{l}-.218 \\
(.057)^{* * *}\end{array}$ & & \\
\hline Foreign ownership & $\begin{array}{l}.224 \\
(.021)^{* * *}\end{array}$ & & \\
\hline Lisbon & $\begin{array}{c}.098 \\
(.010)^{* * *}\end{array}$ & & \\
\hline Share of workers aged $18-24$ & $\begin{array}{l}-.181 \\
(.030)^{* * *}\end{array}$ & $\begin{array}{l}.060 \\
(.027)^{* *}\end{array}$ & $\begin{array}{l}-1.032 \\
(.122)^{* * *}\end{array}$ \\
\hline Share of workers aged $25-29$ & $\begin{array}{c}-.183 \\
(.031)^{* * *}\end{array}$ & $\begin{array}{c}.105 \\
(.027)^{* * *}\end{array}$ & $\begin{array}{l}-.658 \\
(.110)^{* * *}\end{array}$ \\
\hline Share of workers aged $30-34$ & $\begin{array}{l}-.060 \\
(.029)^{* *}\end{array}$ & $\begin{array}{c}.090 \\
(.024)^{* * *}\end{array}$ & $\begin{array}{l}-.224 \\
(.081)^{* * *}\end{array}$ \\
\hline Share of workers aged $40-44$ & $\begin{array}{c}.081 \\
(.031)^{* * *}\end{array}$ & $\begin{array}{l}-.086 \\
(.025)^{* * *}\end{array}$ & $\begin{array}{c}.221 \\
(.081)^{* * *}\end{array}$ \\
\hline Share of workers aged $45-49$ & $\begin{array}{l}.044 \\
(.037)\end{array}$ & $\begin{array}{l}-.222 \\
(.030)^{* * *}\end{array}$ & $\begin{array}{l}0.220 \\
(.113)^{* *}\end{array}$ \\
\hline Share of workers aged $50-54$ & $\begin{array}{l}-.061 \\
(.041)\end{array}$ & $\begin{array}{l}-.301 \\
(.035)^{* * *}\end{array}$ & $\begin{array}{c}.460 \\
(.153)^{* * *}\end{array}$ \\
\hline Share of workers aged 55-59 & $\begin{array}{c}-.217 \\
(.049)^{* * *}\end{array}$ & $\begin{array}{l}-.383 \\
(.041)^{* * *}\end{array}$ & $\begin{array}{c}.438 \\
(.186)^{* * *}\end{array}$ \\
\hline Share of workers aged $60-65$ & $\begin{array}{l}-.544 \\
(.067)^{* * * *}\end{array}$ & $\begin{array}{l}-.481 \\
(.051)^{* * *}\end{array}$ & $\begin{array}{l}.281 \\
(.218)\end{array}$ \\
\hline Share of workers w/ highest level university degree & $\begin{array}{l}2.060 \\
(.076)^{* * * *}\end{array}$ & $\begin{array}{c}.373 \\
(.084)^{* * *}\end{array}$ & $\begin{array}{c}.505 \\
(.151)^{* * *}\end{array}$ \\
\hline Share of workers w/ highest level high-school degree & $\begin{array}{l}1.546 \\
(.071)^{* * * *}\end{array}$ & $\begin{array}{c}.173 \\
(.070)^{* *}\end{array}$ & $\begin{array}{c}.587 \\
(.142)^{* * *}\end{array}$ \\
\hline Share of workers w/ highest level 9 yrs school & $\begin{array}{l}1.065 \\
(.069)^{* * * *}\end{array}$ & $\begin{array}{l}.094 \\
(.065)\end{array}$ & $\begin{array}{c}0.487 \\
(.129)^{* * *}\end{array}$ \\
\hline Share of workers w/ highest level 6 yrs school & $\begin{array}{c}.401 \\
(.066)^{* * *}\end{array}$ & $\begin{array}{l}-.125 \\
(.061)^{* *}\end{array}$ & $\begin{array}{c}0.388 \\
(.121)^{* * *}\end{array}$ \\
\hline Share of workers w/ highest level 4 yrs school & $\begin{array}{c}.219 \\
(.064)^{* * *}\end{array}$ & $\begin{array}{l}-.138 \\
(.057)^{* *}\end{array}$ & $\begin{array}{l}0.017 \\
(.092)\end{array}$ \\
\hline Share of female workers & $\begin{array}{l}-.689 \\
(.017)^{* * *}\end{array}$ & $\begin{array}{l}-.181 \\
(.030)^{* * *}\end{array}$ & $\begin{array}{l}.050 \\
(.041)\end{array}$ \\
\hline Const & $\begin{array}{l}3.660 \\
(.684)^{* * *}\end{array}$ & $\begin{array}{l}4.558 \\
(.635)^{* * *}\end{array}$ & $\begin{array}{l}-.014 \\
(.004)^{* * *}\end{array}$ \\
\hline $\begin{array}{l}\text { Obs. } \\
R^{2}\end{array}$ & 301,328 & 301,328 & 112,861 \\
\hline$R^{2}$ & .406 & .776 & .041 \\
\hline$F$ statistic & 607.933 & 102.971 & 45.09 \\
\hline Hansen-J statistic & & & $\begin{array}{l}14.353 \\
{[0.073]}\end{array}$ \\
\hline
\end{tabular}

Table 3: SAles Regressions (ordinary least squares, FiXed EFFECTs, ANd General METHOD OF MOMENTS).

Note: The OLS regression includes controls for the industry (20 dummy variables) and time (19 dummy variables); the $\mathrm{FE}$ regression includes controls for time (19 dummy variables). In the GMM regression, the equation is estimated in first differences, with the shares of worker ages lagged 2 and 3 periods used as instruments. Firm-clustered robust standard-errors in parenthesis. P-value in brackets. Source: Computations based on Portugal, MTSS (1986-2008). 
decline in workers' productivity as they grow older is not as marked as more naive estimation methods would lead us to believe. Overall, the evidence collected shows that early in the lifecycle both productivity and wages increase at a fast pace. Productivity goes on increasing steadily into old age, to reach a plateau between ages 50 and 59, declining afterwards. Note that at the ages 50 to 59, productivity is larger than at much younger ages, namely at the reference group 35-39. After age 60, the point estimate still suggests a high productivity, even though we cannot preclude the possibility that it goes back to the levels of the reference group (see the very wide confidence intervals). On their side, wages reach a plateau earlier than productivity and even decline at older ages.

Although we cannot extrapolate our results beyond the age of 65 , taken at face value, they would not substantiate concerns over the impact of aging on productivity or profitability. The same would also apply to the consequences of extending the compulsory age of retirement that many governments around the developed world are considering as a means to ease the pressure on their increasingly burdened retirement pension plans. But, as we said, these implications would hold only to the extent that productivity does not decrease severely around the age of 70, which is not what other studies indicate, and would also depend on which workers (if any) would be left out of employment due to older workers remaining in employment for longer periods, not to mention that other issues (such as health status or workers' well-being) could not be ignored if such a policy change were to be considered.

\section{Conclusion}

Using a panel of Portuguese private sector firms that spans for over 20 years and includes detailed information on worker and firm characteristics, we find in our preferred specification that the age-productivity profile of the firm increases with age and peaks at the age interval between 50-54. Afterwards it remains relatively constant. In contrast, age-wage profiles are remarkably flat after the age interval between 25-29 and decline above the age interval between 50-54.

Wages and productivity increase at similar paces only in the early years in employment. From there on productivity continues to increase (due to on-thejob training investments) whereas wages remain mostly constant. This result is consistent with shared investments in on-the-job training, whereby workers recover their investments as their benefits start to emerge and employers receive their share 
of the return later on.

Finally, our results imply that the answer to our title question is positive: older workers are worthy of their pay in the sense that their contribution to production exceeds their contribution to the wage bill.

The comparison between the results of OLS and fixed-effects estimation, on one hand, and GMM estimation, on the other hand, also indicates that failure to account for unobserved firm heterogeneity and endogeneity of changes in factor shares biases the results towards finding evidence of underpayment followed by overpayment policies. Non-random distribution of workers of different ages across firms coupled with selective firing policies, if not properly accounted for, can be mistaken for older workers being overpaid. 


\section{References}

Arellano, Manuel and Stephen Bond (1991). Some tests of specification for panel data: Monte Carlo evidence and an application to employment equations. Review of Economic Studies, 58: 277-297.

Avolio, Bruce J. and David A. Waldman (1994). Variations in cognitive, perceptual, and psychomotor abilities across the working life span: Examining the effects of race, sex, experience, education, and occupational type. Psychology and Aging, 9: 430-442.

Aubert, Patrick and Bruno Crépon (2003). La productivité des salariés âgés: Une tentative d' estimation. Économie et Statistique, 368: 95-119.

Bartel, Ann P., and Nachum Sicherman (1993). Technological change and the retirement decisions of older workers. Journal of Labor Economics, 11(1): $162-83$.

Dostie, Benoit (2006). "Wages, productivity and aging." IZA discussion paper 2496. Bonn: Institute for the Study of Labor.

Diamond, Arthur (1986). The life-cycle research productivity of mathematicians and scientists. Journal of Gerontology, 41: 520-525.

Fair, Ray C. (1994). How fast do old men slow down? Review of Economics and Statistics, 76 (1): 103-118.

Foster, Lucia, John Haltiwanger and C. J. Krizan (2001). "Aggregate productivity growth. Lessons from microeconomic evidence." in Charles R. Hulten, Edwin R. Dean and Michael J. Harper (eds.) New Developments in Productivity Analysis. Chicago: University of Chicago Press, p. 303-372.

Galenson, David W. and Bruce A. Weinberg (2000). Age and the quality of work: The case of modern American painters. Journal of Political Economy, 108(4): 761-777.

Göbel, Christian and Thomas Zwick (2009). Age and Productivity - Evidence from Linked Employer Employee Data. ZEW discussion paper 09-020. Mannheim: Centre for European Economic Research (ZEW).

Hægeland, Torbjorn and Tor Jakob Klette (1999). "Do higher wages reflect higher productivity? Education, gender and experience premiums in a matched 
plant-worker data set." in John C. Haltiwanger, Julia I. Lane, James R. Spletzer, Jules J. M. Theeuwes and Kenneth R. Troske (eds.) The Creation and Analysis of Employer-Employee Matched Data. Amsterdam: North-Holland, p. 231-259.

Haltiwanger, John, Julia Lane and James Spletzer (1999). Productivity differences across employers: The roles of employer size, age, and human capital. American Economic Review, 89: 94-8.

Hellerstein, Judith K. and David Neumark (1995). Are earnings profiles steeper than productivity profiles? Evidence from Israeli firm-level data. Journal of Human Resources, 30(1): 89-112.

Hellerstein, Judith, David Neumark and Kenneth Troske (1999). Wages, productivity, and worker characteristics: Evidence from plant-level production functions and wage equations. Journal of Labor Economics, 17(3): 409-446.

Lallemand, Thierry and François Rycx (2009). "Are young and old workers harmful for firm productivity?" IZA discussion paper 3938. Bonn: Institute for the Study of Labor.

Lazear, Edward P. (1979). Why is there mandatory retirement? Journal of Political Economy, 87(6): 1261-1284.

McDowell, John (1982). Obsolescence of knowledge and career publication profiles. American Economic Review, 72: 752-768.

Medoff, James L. and Katharine G. Abraham (1980). Experience, performance, and earnings. Quarterly Journal of Economics, 95(4): 703-736.

Oster, Sharon M. and Daniel S. Hamermesh (1998). Aging and productivity among economists. Review of Economics and Statistics, 80(1): 154-156.

Portugal, Ministério do Trabalho e da Segurança Social (1986 to 2008). Quadros de Pessoal. Data in magnetic media. Lisbon: MTSS.

Skirbekk, Vegard (2003). Age and individual productivity: A literature survey. MPIDR working paper 2003-028. Rostock: Max Planck Institute for Demographic Research.

van Ours, Jan C. and Lenny Stoeldraijer (2010). "Age, wage and firm productivity" CenTER discussion paper 2010-12. Tilburg: Department of Economics, Tilburg University. 


\section{Appendix - additional figures}

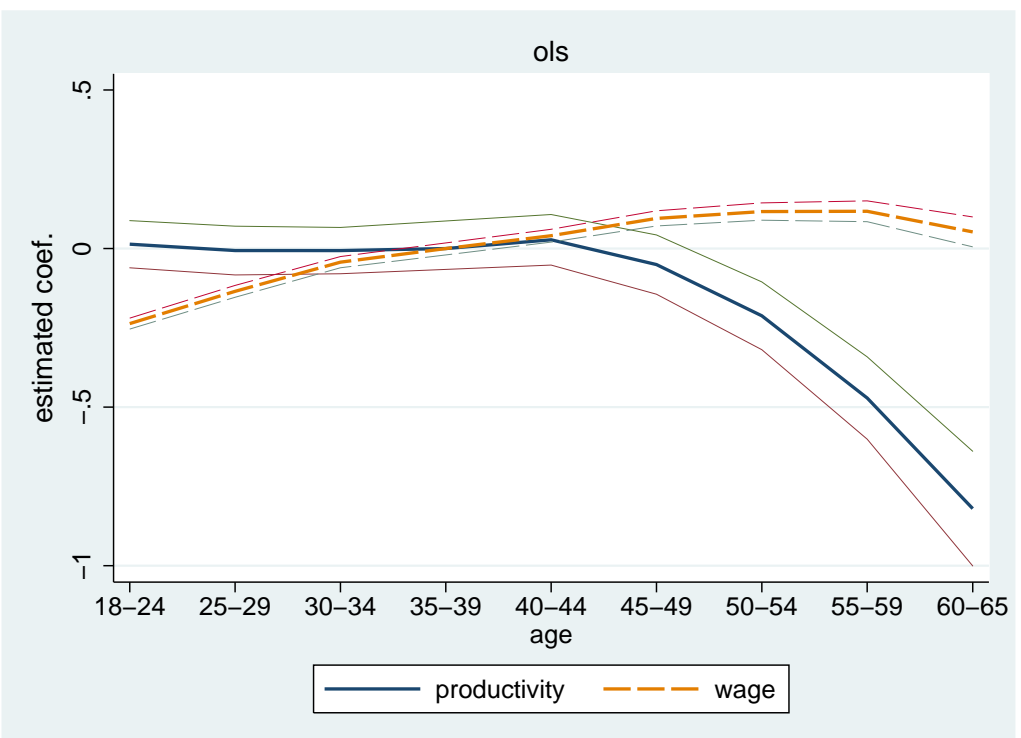

Figure 4: Production and wage cost functions, Ordinary Least Squares estimation, MANUFACTURING. Source: Computations based on Portugal (1986 to 2008).

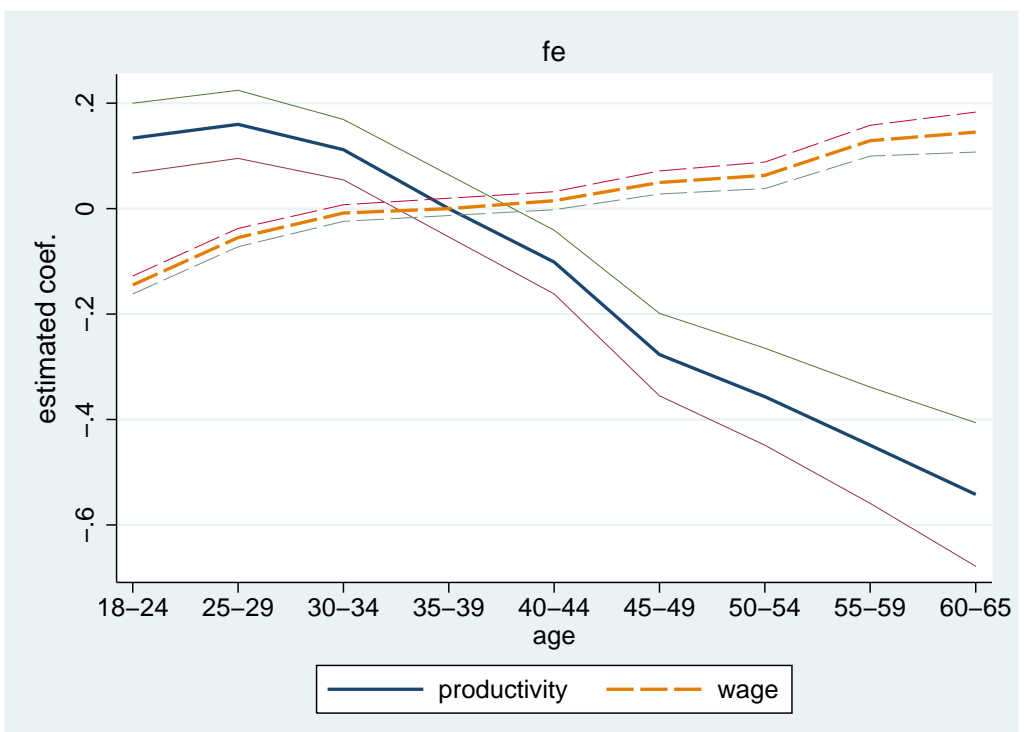

Figure 5: Production and Wage cost functions, Fixed Effects estimation, ManufacTURING. Source: Computations based on Portugal (1986 to 2008). 


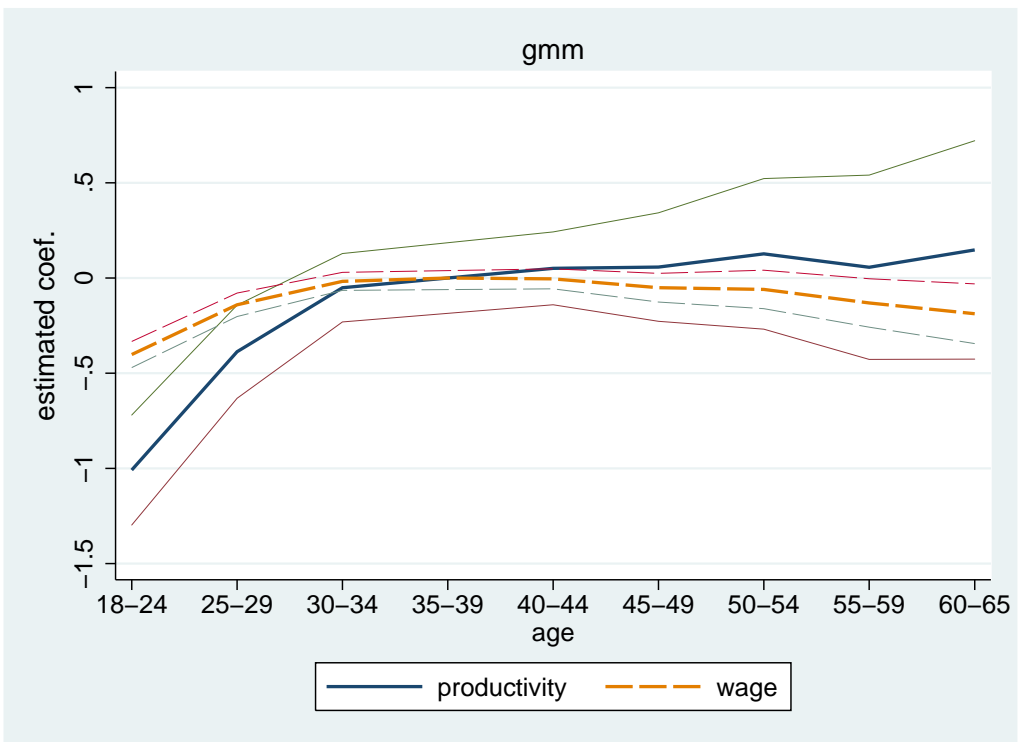

Figure 6: Production and wage cost functions, General Method of Moments, manUFACTURING. Source: Computations based on Portugal (1986 to 2008).

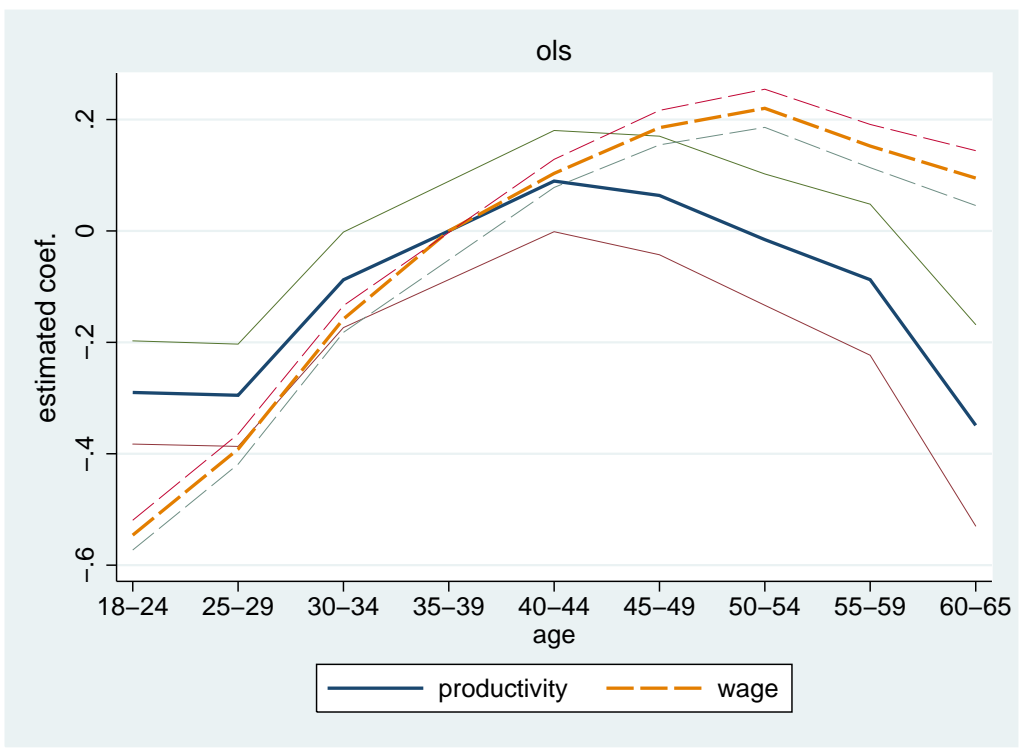

Figure 7: Production and wage cost functions, Ordinary Least Squares estimation, SERVICES. Source: Computations based on Portugal (1986 to 2008). 


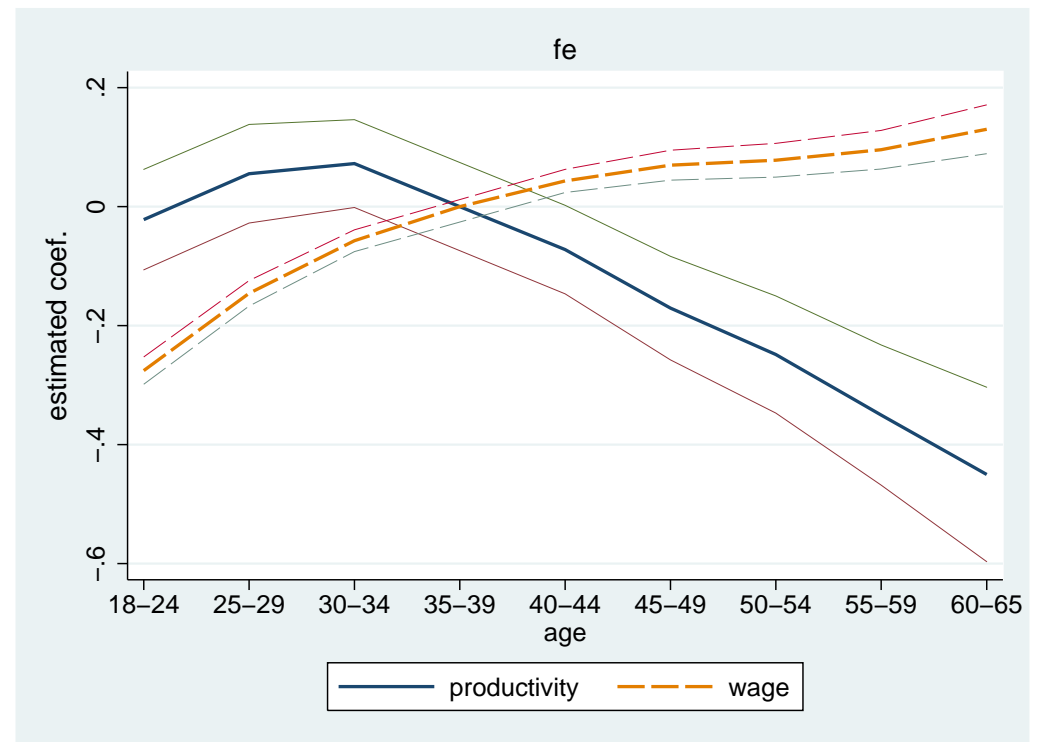

Figure 8: Production and wage cost functions, Fixed Effects estimation, services. Source: Computations based on Portugal (1986 to 2008).

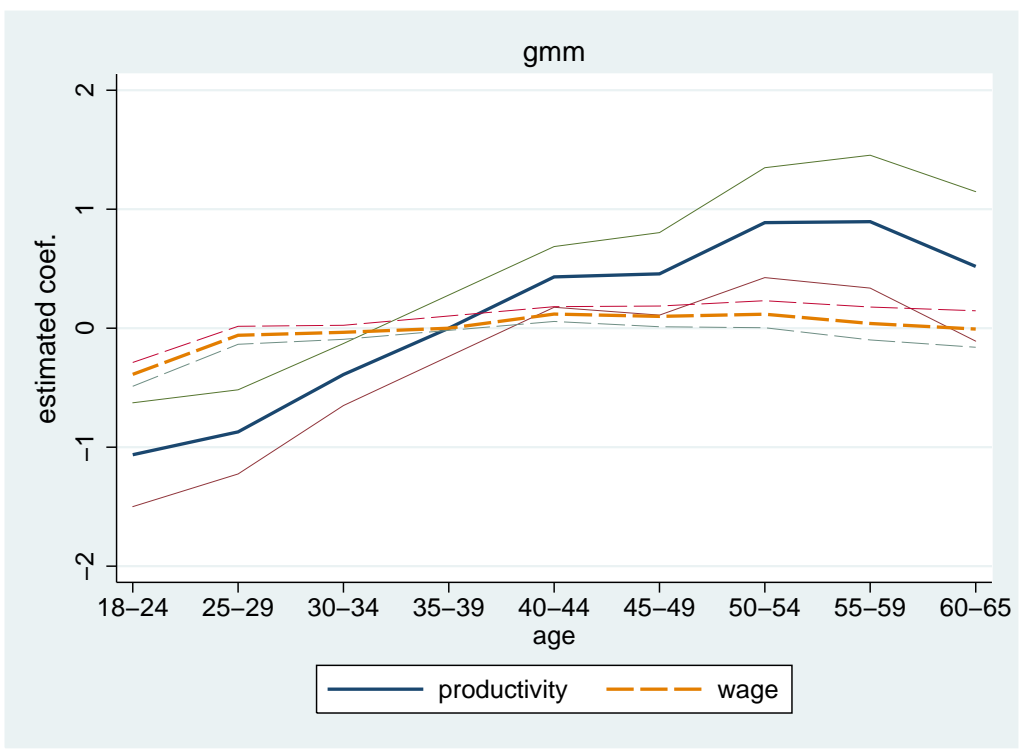

Figure 9: Production and wage cost functions, General Method of Moments, serVICES. Source: Computations based on Portugal (1986 to 2008). 